\title{
DECOLONISING IMAGES? THE LIBERATION SCRIPT IN MOZAMBICAN HISTORY TEXTBOOKS
}

\author{
DOI: http://dx.doi.org/10.17159/2223-0386/2020/n24a1
}

Rosa Cabecinhas

Universidade do Minho, Braga, Portugal cabecinhas@ics.uminho.pt

ORCID No.: orcid.org/0000-0002-1491-3420

\author{
Martins Mapera \\ Universidade Zambeze, Beira, Mozambique \\ martins.mapera@uzambeze.ac.mz \\ ORCID No.: orcid.org/0000-0002-7476-2986
}

\section{Abstract}

In this article we examine the textbook narratives of the colonial past and the nation-building process in Mozambique, a Southern African country which gained its independence in 1975. One of the priorities after independence was to redesign the state apparatus and social system in order to decolonise people's minds, foster patriotism and strengthen national cohesion. We have conducted a discourse analysis of the verbal and iconic content of two Mozambican history textbooks, which are exclusively dedicated to national history: one published during the singleparty or "socialist" phase; and the other published in the multi-party or "neoliberal" phase and currently in use. For this purpose, we developed an analytic framework to unveil how the textbooks' written and visual repertoires, and the combination thereof, convey (or otherwise) a diverse and inclusive vision of the nation. Our findings reveal that although there have been changes in the types of language and images used, the general account of Mozambican history remains identical, emphasising the need for national unity under the leadership of the ruling political elite and recounting the History of Mozambique from the perspective of a single Liberation script, that completely overlooks the agency of women.

Keywords: Africa; Decoloniality; History education; Intersectionality; Mozambique; Nationalism.

In this article we examine History textbook narratives about the nationbuilding process in Mozambique, a multilingual country (Lopes, 1998) in Southern Africa bordered by the Indian Ocean. According to Israel (2013:11), the Mozambican case can be viewed as both "paradigmatic" and "extreme". On the one hand, it is "paradigmatic of a southern African tendency, whereby the political legitimacy acquired in liberation struggles," in this case against Portuguese colonialism - "generated a triumphalist historical narrative, which became an instrument of state and nation-building, a catalyst of collective identities, and a tool of power." On the other hand, it is an "extreme" case, in the sense that "a prolonged 
anti-colonial struggle gave way to a socialist experiment [...], led by a charismatic leader of a revolutionary party" (Israel, 2013:11). Therefore, "in Mozambique the liberation narrative seemed to promise a victory not only against colonialism and conjunctural Cold War enemies but also against the exploitation of man by man" (Israel, 2013:11). However, the "very dramatic" recent history lived by Mozambicans (Arnfred, 2004:106), shows that the dream that it will be possible to eradicate extreme inequality is far from being achieved.

After the proclamation of the People's Republic of Mozambique in 1975, one of the priorities of the Mozambique Liberation Front (FRELIMO) was to redesign the state apparatus and the social system in order to overcome the colonial mindset, foster patriotism and strengthen national cohesion (Basílio, 2010). Education was perceived as the driving force for the envisioned social and economic progress. But qualified national teaching staff and material resources were scarce. In order to overcome the huge rates of poverty and illiteracy inherited from the colonial era, the FRELIMO government built upon the educational experiences initiated in the liberated areas during the armed struggle. While the Mozambican government was struggling to redesign the state apparatus, the so-called Cold War gained ground in the region (Piepiorka, 2020). In this context, the "post-independence development in education was triggered by foreigninduced impulses, stemming from 'socialist solidarity" (Piepiorka, 2020:289). "Cooperantes" from a variety of countries (Brazil, Canada, Italy, Portugal, Nordic countries, among others; Cf. Isaacman \& Isaacman, 1983; Gasparini, 1989), worked as educational advisors, schoolteachers, curriculum designers, etc., together with local teams in the huge and challenging task of creating an approach that aimed to overcome "both traditional and colonial modes of education", fighting oppressive systems of class divisions (Barnes, 1982:407). These post-independence socialist goals were integrated into the Mozambican national education system, implemented in 1983.

One of the main priorities was to re-write history and disseminate a new narrative of the nation to rescue dignity. The new curriculum materials emphasised the history of resistance and the role played by the armed liberation struggle (Barnes, 1982) in the nation-building process. As in other contexts, the need to legitimise the new political order led to the construction and dissemination of a single account of national history. According to Coelho (2013), the "Liberation script" disseminated in the 
public sphere emphasised the armed liberation struggle against colonialism, primarily through binary opposites: revolutionary versus colonialist, exploiter versus exploited, and so on. This "usable past" (Wertsch, 2002) was disseminated by various instruments of the state, including the education system and the media.

Since 2010 there has been a growing body of research into Mozambican public memory and social representations of national history (e.g. Cabecinhas \& Feijó, 2010) as well as critical reflection on the "Liberation script" (Coelho, 2013) in the Mozambican public sphere, in particular analysis of how this liberation script has been conveyed via political discourses, films, novels, biographies, etc. (e.g. Israel, 2013; Meneses, 2011; Schefer, 2016). However, there has been very little research into Mozambican history textbooks.

Cabecinhas, Macedo, Jamal and Sá (2018) developed a synchronic analysis of the representations of European colonialism and liberation struggles in current History curricula and textbooks for lower and upper secondary school education in Mozambique. Cabecinhas, Jamal, Sá and Macedo (2021) conducted a diachronic analysis of the Liberation script in Mozambican history textbooks since independence. In this article, we examine the representations of national history conveyed in two Mozambican history textbooks, published in distinct phases: the singleparty or "socialist" phase; and the multi-party or "neoliberal" phase. While previous work has focused solely on the verbal content, in this article we will also analyse the iconic dimension, using exploratory multimodal analysis (Kress \& van Leeuwen, 2001; van Leeuwen \& Selander, 1995), informed by an intersectional framework (Crenshaw, 1989; May, 2015), which acknowledges that oppression is not a single-axis phenomenon, but a complex one, involving multiple social groups. Such an intersectional framework is particularly relevant for the context of Mozambique, since the Liberation struggle aimed to fight against all kind of oppressions and thereby create a nation that would be free from any kind of discrimination, in particular racism and sexism.

In the following sections we provide a brief context for our study, presenting the analytic framework and the Mozambican historical and educational background. We then present a multimodal analysis of the Liberation script in two Mozambican History textbooks, published in different political phases. The two textbooks analysed herein obviously do 
not constitute a representative sample of all History textbooks published since 1975. Our aim is far more modest: to reflect on how the images chosen and incorporated in these textbooks may contribute to the task of decolonising historical knowledge; and the extent to which the visual elements are aligned with the text, to convey a single script of the nationbuilding process. We will not, therefore, provide a systematic multimodal analysis, including linguistic and layout structures (Kress \& van Leeuwen 1990), nor a comprehensive analysis of the verbal and visual text in the two textbooks. We will pay particular attention to the verbal and iconic representations of the colonial past and the liberation struggle and how they convey group and individual agency, in a way that challenges or reinforces the colonial legacy.

\section{Picturing the nation and decolonising historical knowledge}

Debates on how the colonial past is interpreted and how it is taught in schools are crucial (Carretero, Berger \& Grever, 2017; van Nieuwenhuyse \& Valentim, 2018) as well as the need to move away from traditional dichotomies between Eurocentric and Afrocentric perspectives in history education. Nowadays there is a huge worldwide controversy about history education (Cajani, Lässig \& Repoussi, 2019). Different trends can be observed around the world concerning the ways of operationalising a "multicultural", "cosmopolitan", or "global" history education, in order to promote multi-perspectivity and a culture of peace. However, despite the recommendations established by international organisations, such as UNESCO, history education continues to be a privileged arena for the State's soft power, aiming to foster patriotism (often confused with nationalism) and convening a vision of the past which legitimises the current political order (Wertsch, 2002).

History education, like other instruments of the State, establishes guidelines on what should be remembered from the nation's past, and also how it should be remembered (Valsiner \& Marsico, 2019), establishing a link between dominant meaning systems or hegemonic social representations (Moscovici, 1988) and personal experiences. According to Valsiner and Marsico (2019), historical memory is "socially suggested to be fragmented, superficial, and affectively accepting the hegemonic message encoded in the words of the parents (about ones great-great-grandparents), school history textbooks, and public monuments" (Valsiner \& Marsico, 2019:vi). Several studies have demonstrated the longstanding impact of education 
and textbooks on the political worldviews of young people, which may even be detectable at an adult age (Ide, Kirchheimer \& Bentrovato, 2018).

Remembering is a constructive process (Bartlett, 1933) embedded within a specific cultural context and cannot be understood without taking into account the interplay between cognition, affect, identity dynamics, asymmetric power relations and cultural symbols. For example, Wagoner, Bresco and Awad (2019) stress the need for conducting qualitative analysis in order to examine how remembering is transformed over time, according to the systems of meaning of a given society and its historical transformation. Assuming an interdisciplinary perspective, in this article we will focus on history education in Mozambique, conducting an exploratory multimodal analysis of the visual "Liberation script" in two textbooks published in different political moments.

Taking into account the extremely asymmetric power relations during the period of European Imperialism and the way that they pervasively undermined the wealth, well-being, self-esteem and self-confidence of former colonised peoples, one of the priorities of African liberation movements has been to rewrite history in order to overcome Eurocentric perspectives. However, according to Chakrabarty, despite the development of alternative historiographies, "'Europe' remains the sovereign, theoretical subject of all histories", functioning "as a silent referent in historical knowledge" (1992:1-2).

This "silent referent" works not only through the text (concepts used to describe historical processes and periods), but also through the images, since African textbooks usually rely on the colonial archive (photographs of documents, etc.) to illustrate historical events and figures. As will be shown below, the need to tell history from a Mozambican perspective led to the creation of original illustrations (drawings, photographs, infographics and maps) to be incorporated into history textbooks.

In this article we will focus on the efforts made to challenge Europe as a "silent referent" of historical knowledge and to decolonise history education through the use of local sources and images. We will pay particular attention to the images of historical figures. An intersectional decolonial framework was developed to analyse these images, considering that each person pertains to multiple social groups (socially constructed in terms of gender, race, ethnicity, nationality, social class, age group, etc.), occupying asymmetric positions in a given society. In Mozambique, the 
Liberation struggle was presented as a fight against two main forms of oppression - the "colonial" and the "traditional" - which had a particularly strong impact on women. Women's emancipation was considered to be crucial for achieving liberation, as expressed in Samora Machel's famous statement during the inaugural meeting of the Organisation of Mozambican Women (Organização da Mulher Moçambicana; OMM) in 1973: "The liberation of women is a necessity for the revolution, a guarantee of its continuity and a condition for its success" (Arnfred, 2004:109).

\section{Overcoming the colonial education system and Mozambican history textbooks}

By the 1960s, almost all former African colonies had gained independence and Portugal had the only European colonial empire that had not collapsed. The political ideology and national historiography, under the Estado Novo dictatorship, steeped in strongly Eurocentric and nationalistic assumptions, praised Portugal's “civilising mission” (Jerónimo, 2015). Portugal's former African colonies gained their independence in the mid-1970s, after Portugal's 1974 Carnation Revolution and a long liberation war in Angola, Portuguese Guinea, and Mozambique (Valentim \& Miguel, 2018).

According to Arnfred (2004:106) "the recent history of Mozambique has been very dramatic. There have been several changes of political regimes, and almost three decades of war, from the onset of the armed struggle in 1964 to the Rome Peace Agreement in 1992", ending the "16 years" conflict/civil war. Two remarkable political shifts are identified:1) the transition in 1975 from Portuguese colonialism to political independence and FRELIMO socialism; 2) the transition from FRELIMO socialism to neo-liberal economic policies and a structural adjustment programme coordinated by the World Bank, since the early 1990s. Arnfred adds that although "these decades of history include dramatic changes in government", in which Mozambicans moved "from colonial dominance economy in a one-party state, to multi-party democracy and neo-liberal economic structures", these changes are "overshadowed by persistent continuities" (2004:106). In fact, today's power structures remain concentrated around FRELIMO, providing "a layered form of social stratification within the nation" (Sumich, 2010:679), a situation which contrasts with the utopian dreams proclaimed during the liberation struggle.

After independence, the main priority for the education system was to form a "New Man", who would have a patriotic and revolutionary 
consciousness, free from colonial thoughts or any other form of domination (Cabaço, 2007; Mazula, 1995). The prevalence of a colonial mindset in a large part of the population and the fact that people identified themselves on an ethnic, tribal and regional basis were considered to be obstacles to national unity (Mazula, 1995). These problems led to the emergence of an educational model based on Marxism-Leninism values, in which tradition and cultural diversity were seen as a barrier to building the new order (Cabaço, 2007). The process of nation-building was based on erasing local cultural traditions, which allegedly contributed to obscurantism (Basílio, 2010). In this political context, a single vision of the colonial past was constructed and mobilised by political leaders, and also in the education system, to gather the people around the "nation", ignoring distinct ethnicities and different experiences, in which the "heart of national history is located in the memory of the struggle for national liberation" from colonialism (Meneses, 2011:130). Appealing to unity, the nationalist narrative generated profound contradictions as well as continuities with modern oppression mechanisms (Meneses, 2011).

The collapse of the USSR, brought significant changes to Mozambique's political system. The end of the civil war (1976-92) led to opening of democracy and the transition to a multi-party system. However, the liberalisation of the economy and higher foreign investment did not eradicate poverty or huge regional disparities (Castiano, 2019). In the education system, the transition from a "socialist" to a "neoliberal" phase led to implementation of curricular reforms and an opening to the private sector, but still maintained inequalities in terms of access to high-quality education (Castiano, 2019).

According to the Ministry of Education (MINED, 2012:21), since the country gained independence, Mozambique's Education System had had three distinct periods: 1975-1979 - nationalisation of Education and the expansion of the school network and enrolment; 1980-1992 - shrinking of the school network due to the civil war; 1992 onwards - after signature of the Peace Agreement in 1992 there has been major expansion of the school network and enrolment, and the opening of private schools and universities. In 2004, Public Primary School Education was restructured, through introduction of a new curriculum aimed at offering seven years of basic education to all, although this goal is still far from being achieved. The curriculum of the General Secondary School Education was restructured in 2008, introducing "multicultural education", oriented 
towards entrepreneurship and the global market. Public Primary School Education is free, with provision of free textbooks, whereas in Secondary School Education there are tuition fees and no provision of free textbooks. Secondary School attendance rates remain very low today (MINED, 2019).

A new education reform was recently approved (Law no. 18/2018, of December 28) that aimed to "Harmonise current educational policies with regional education initiatives within the framework of the Southern African Development Community (SADC) and, at the level of the African continent, within the framework of the African Union Vision 2063 and its Continental Education Strategy for Africa (2016-2025)" (MINED, 2019: 10). According to the new law, public Primary School Education will cover six years (instead of the current seven years) and History, as an autonomous subject, will be removed from the curriculum.

After independence, History was a priority subject and was compulsory in primary and secondary schools. History is now taught as a separate subject in secondary school education: in the lower level of secondary school (years 8 to 10) students learn about "universal history", including Mozambican history, while the upper level is dedicated to African history (year 11) and Mozambican history (year 12). The 2018 reform aims to include History within a general subject of "Social Sciences", but the new curricular directives haven't yet been defined.

Mozambican textbooks follow the mandatory curricula defined by the Ministry of Education. In the 2000s there was an opening, which enabled different publishing houses to produce textbooks, and a list of various textbooks was approved by the Ministry of Education for each year/ subject. However, since 2017, a single textbook is recommended for each year/subject. In the case of History, the textbooks published by Texto Editores (which has its headquarters in Portugal) were chosen to be used in all school years (Cabecinhas et al., 2018).

\section{Narrating the nation: The (visual) liberation script in textbooks about Mozambican history}

In this article we compare two textbooks which focus exclusively on national history: A História da minha pátria. $5^{a}$ Classe [The history of my homeland. Year 5] (INDE, 1986) was the first textbook entirely dedicated to Mozambican history published after implementation of the Mozambican National Education System (1983); and H12 História [History, Year 12] 
(Mussa, 2015), resulting from the most recent curricular reform and the one that is currently in use.

As mentioned above, in this article we will pay attention to the efforts made to overcome Europe as a "silent referent" and to decolonise history education, by challenging colonial conceptualisations and using local sources and images. In terms of images, we will focus exclusively on images of people and the way that these images reinforce or challenge asymmetries of power. For this purpose, we have adapted the semiotic multimodal analysis grid proposed by Kress and van Leeuven (2001), - in particular that which they call "representational meanings" (representation of human participants: gender, ethnicity, age, social status, occupation) and "compositional meanings" (framing) - with an intersectional approach (e.g. Crenshaw, 1991; May, 2015) in order to engage with complexity, rather than analysing each element in isolation. In addition to looking at the combination of the elements found therein, we also considered the absent elements. The images reproduced in this article aim to question the "silent" referents in the narration of the nation. The captions provided below correspond to the captions that appear in the textbooks (translated into English).

\section{Decolonising the archive}

The textbook A História da minha pátria (INDE, 1986) was written by a "collective of authors" whose names are indicated in the book's technical credits, alongside the authors of the illustrations and graphic arrangements and the archives used (in particular the Mozambican magazine Tempo, the Historical Archive and the Museum of the Revolution). No sources are identified for the images, nor is there any reference or bibliography list. There is recurring use of expressions such as "we", "we, Mozambicans" with an emphasis placed on oral testimonies (mainly from peasants and freedom fighters) and speeches by FRELIMO leaders, who have the highest number of photographs in this textbook, in particular Eduardo Mondlane, FRELIMO's first president, who was assassinated in 1969, and Samora Machel, Mozambique's first President, who died in a plane crash on October 19, 1986, a few weeks before this textbook was published. In fact, the textbook concludes with a tribute to Samora Machel: "The father of the nation is dead" (INDE, 1986:109) and the final page is dedicated to "Joaquim Alberto Chissano, successor of Samora and Mondlane", with a photograph of the new president, highlighting FRELIMO's role "in the fight against 
tribalism, regionalism, racism and other forms of division of the People, and which has helped form the Mozambican Nation" (INDE, 1986:112).

In INDE (1986) the oral testimonies are presented as having evidential status, conveying the truth. The textbook contains various testimonial elements - in the form of photographs, illustrations, maps, chronological charts and other documents, all in black and white. The majority are original materials (drawings, charts and photographs), complemented by a few illustrations from various archives. Both oral testimonies and material and archaeological evidence are used to rescue "Mozambique's long history" (p. 7), contradicting the Eurocentric narrative that Africa had no history before the arrival of the Europeans. The elders (Image 1: Council of Elders) symbolise the preservation of endogenous wisdom and history.

The textbook H12 História (Mussa, 2015) is illustrated with coulor photos, figures, graphs and maps, but none of the sources are indicated. The tables are the only illustrations that are always accompanied by a source. There is a bibliography at the end, which includes both Mozambican and foreign sources, predominantly African and European. This textbook also stresses the importance of oral history and material and archaeological evidence in order to recover Africa's history. The textbook states that historical sources are a crucial subject and dedicates the first chapter to discussing the problem of sources for the different periods in the History of Mozambique. The interpretative nature of historical knowledge is addressed, including problems related to availability, credibility, access and distribution of sources for the reconstitution of the history of Mozambique, and stressing the need for oral sources, since "colonial historiography left a fragile base in terms of source structures (...) a poor record of popular struggles against the colonial system" (Mussa, 2015:12). In this context, the textbook includes excerpts from the book Mozambique, 16 Years of Historiography (1991:17-27) which states that the almost complete absence of historical sources in post-independence textbooks is due to the fragile documentary legacy left by colonial historiography, which means that retracing the country's history depends on ethnographic descriptions, travellers' reports and some legal support from the Portuguese administration. Taken as a whole, this "makes historical reconstruction of the country very difficult" (Mussa, 2015: 12). The gaps are being filled by oral testimonies, which in many cases are the only available sources. The text explains: "Because there is still a lack of reliable, written information for the reconstruction of certain periods in our country's history, oral sources are extensively 
used in the History of Mozambique" (Mussa, 2015:12). Another passage from the same excerpt adds : "We cannot (...) forget that in any historical era or period the class in power determines a certain type of historical production, a manipulation for which researchers should always be aware" (Mussa, 2015:12), denoting a critical position in relation to the lack of impartiality of this type of testimony, and laying a bridge towards the limitations of written sources in Mozambique. It is therefore necessary to resort to material and archaeological sources, as well as secondary sources, in particular those from other countries, but which raised difficulties of interpretation due to insufficient mastery of their languages, such as Arabic and Hebrew (Mussa, 2015). A photograph of an "elder who guards the Chinhamaperi rock art engravings in Manica" (Image 2) symbolises the importance of ancient history.

Image 1: Council of Elders

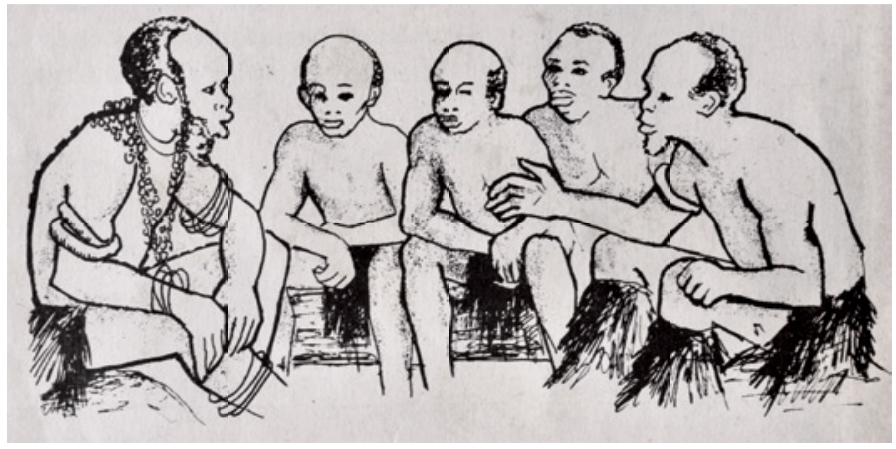

Source: INDE, A História da minha pátria. $5^{a}$ classe, 1986, p. 12.

Image 2: Elder who guards the Chinhamaperi rock art engravings in Manica

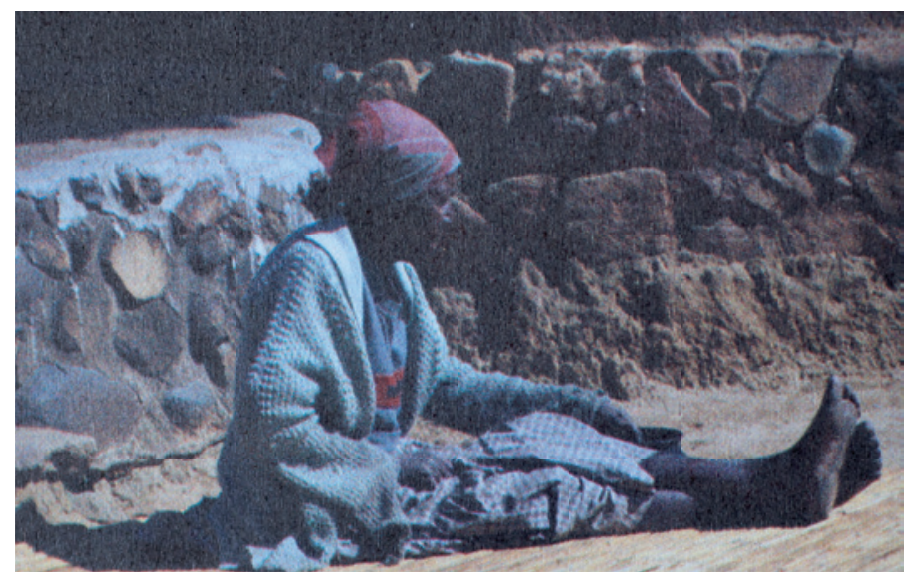

Source: C Mussa, História 12a classe, 2015, p. 12. 


\section{Contesting the colonial mindset}

INDE (1986:4-7) begins with a short chronological overview of Mozambican history, divided into six periods: "Ancient kingdoms and empires"; "Arab presence", "Portuguese incursions into Mozambique and resistance"; "Effective occupation of Mozambique"; "The armed National Liberation struggle"; and "Independent Mozambique". The first chapter, intitled "The people of Mozambique many, many years ago", emphasises the ancient history of the Mozambican people and the lifestyle of small communities, based on harvesting, hunting and fishing. The second chapter describes the arrival and settling of the Bantu people, emphasising the formation and decline of several kingdoms, in particular Great Zimbabwe, Mwenemutapa, Marave, Yao and Gaza. The third chapter covers the "Arab presence", the "Portuguese penetration" and the "Prazos" of the Zambezi river valley. The fourth chapter corresponds to "effective occupation" by the Portuguese and Mozambican resistance. The fifth chapter is about the armed struggle for national liberation, and the sixth chapter covers Mozambique after independence.

In Mussa (2015) the classification of the different periods of Mozambican history is somewhat similar, but is only divided into five periods, since the armed liberation struggle is presented as the final phase of the fourth period. Independent Mozambique corresponds to the fifth period, which is divided into two phases: the single party phase; and the multi-party phase, since 1990/4. Ironically, the image chosen to identify Unit 1 - dedicated to the periodisation of Mozambican history and highlighting the need to move beyond the colonial archive - is a photograph of a bas-relief representing the imprisonment of Ngungunyane, the last emperor of Gaza, in December of 1895 , considered to be the moment that signalled the beginning of Portugal's "effective occupation" of Mozambique (Image 3). The same image, where Ngungunyane is portrayed in a position of submission, is shown on three occasions in this textbook. Furthermore, Ngungunyane is the only Mozambican identified in images covering the periods prior to independence.

Ngungunyane is also highlighted as a symbol of resistance in INDE (1986), and is once again the only Mozambican from this period to be identified in a photograph that indicates his name, but with a different image: a photograph where Ngungunyane is with his family, after being deported to the Azores (Image 4). 
Image 3: The imprisonment of Ngungunyane

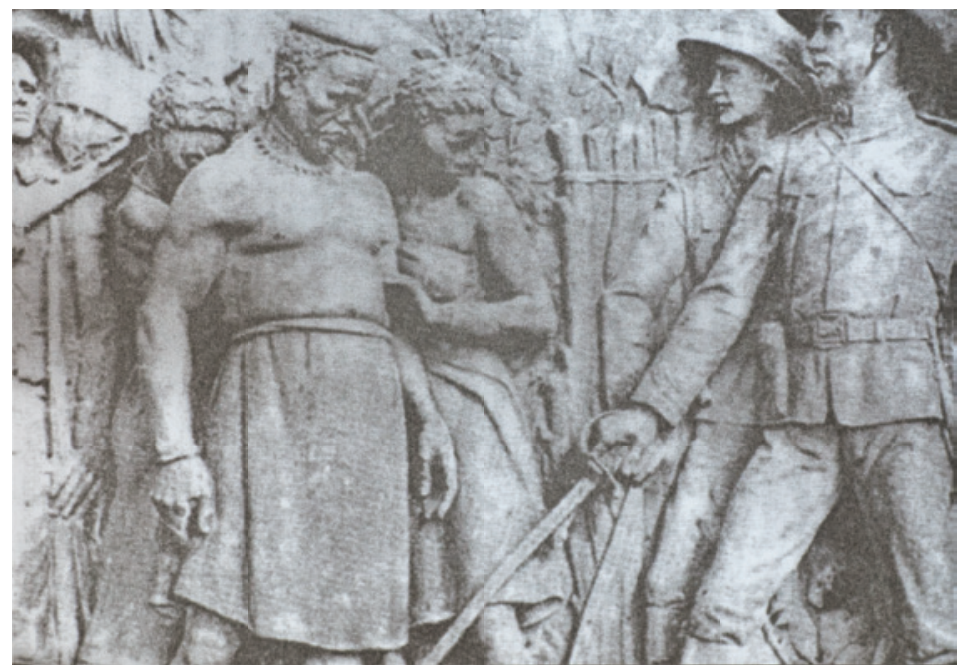

Source: C Mussa, História 12a classe, 2015, p. 81.

Image 4: Ngungunyane with his son (Godigo), the uncle (Mulungo) e Matibjana (Zixaxa) in Portugal

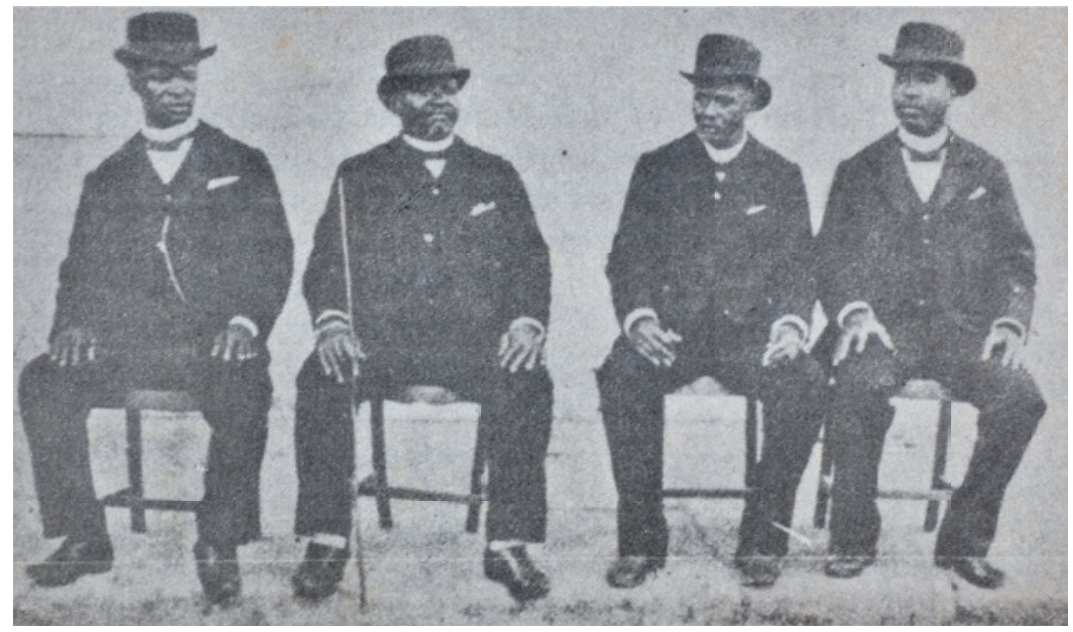

Source: INDE, A História da minha pátria. $5^{a}$ classe, 1986, p. 45.

As mentioned above, both textbooks distinguish two periods of colonialism in Mozambique: "foreign mercantile penetration" and "effective occupation of Mozambique" or "aggressive imperialism". However, the type of images chosen to illustrate these periods are quite distinct. INDE (1986:21) states that "in 1498 the first Portuguese explorers, led by Vasco da Gama, arrived 
in Mozambique. They were interested in our riches, in particular our gold and ivory". The Portuguese attacked the Arabs and formed alliances with some of the local chiefs, who "authorised the Portuguese to settle and trade, under certain conditions. A tax was introduced called the 'Curva'. When entering Zimbabwe, ruled by the Mwenemutapa, the Portuguese could not wear hats or bear weapons and had to clap their hands as a sign of respect" (INDE, 1986:23). This asymmetry of power relations is represented in Image 5, where the Mwenemutapa is shown in a higher position and the Portuguese in a submissive posture and lower position, in contrast with the dominant Eurocentric narrative, which portrays colonialism as a top-down process, controlled by European agency.

INDE (1986) notes that "from the outset, the Portuguese colonialists encountered strong resistance from the Mozambican people. However, some Mwenemutapas betrayed our People's heroic resistance. This betrayal led to rebellions and internal struggles, such as the 1596 revolt, in which the Mambos in Quiteve and Manica revolted against Gatsi-Rusere controlled by the Mwenemutapa, which allowed Portuguese merchants and soldiers to enter and establish their empire" (INDE, 1986:23). It is explained that the conflicts between the different groups were encouraged by the "Portuguese colonialists", who "unleashed wars against the people of Mozambique to steal their riches. But, the people of Mozambique resisted the Portuguese colonialists. The latter were often defeated by brave chiefs and warriors" (INDE, 1986:39). The textbook highlights "the internal struggles between Mozambicans, the betrayal of some chiefs who allied themselves with the Portuguese and the religious influence, which allowed the colonialists to begin exploiting our country [...]. Until the 19th century, Portuguese penetration into the hinterland and the effective occupation of our country was always difficult, due to the heroic resistance of the Mozambican people" (INDE, 1986:42). A reference is also made to the resistance to forced labour (xibalo) in different parts of the country and the alliances forged by the Portuguese with other colonial powers to exploit the country. Despite these adversities, "our culture always resisted colonialism" (INDE, 1986:56).

While in INDE (1986) slavery is illustrated with three drawings (for example, Image 6) and forced labour is illustrated with several photographs, the current textbook (Mussa, 2015) also devotes special attention to slavery and force labour, highlighting the violation of human rights and its undermining effects, contributing to the underdevelopment 
of Mozambique today, but these topics are not illustrated with images. Image 5: Mwenemutapa receives the Portuguese

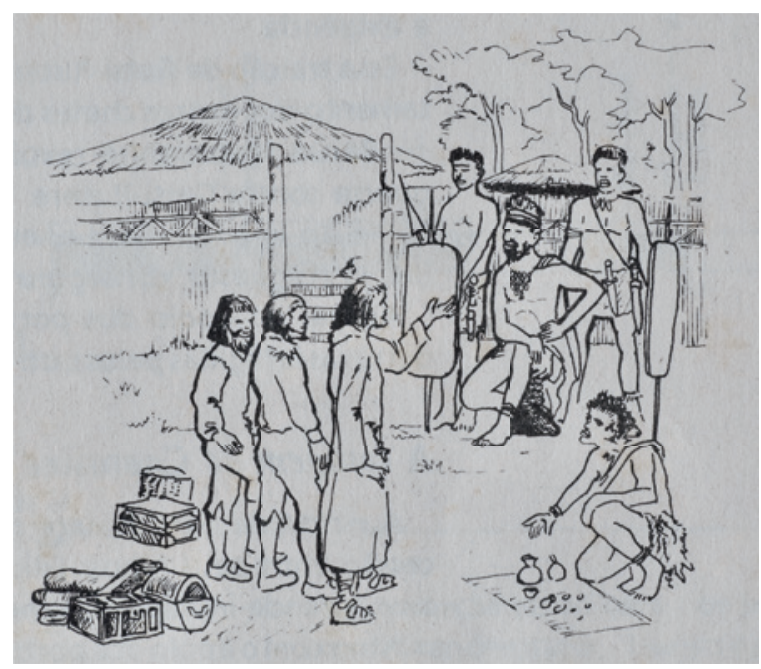

Source: INDE, A História da minha pátria. $5^{a}$ classe, 1986, p. 23.

Image 6: Slavery

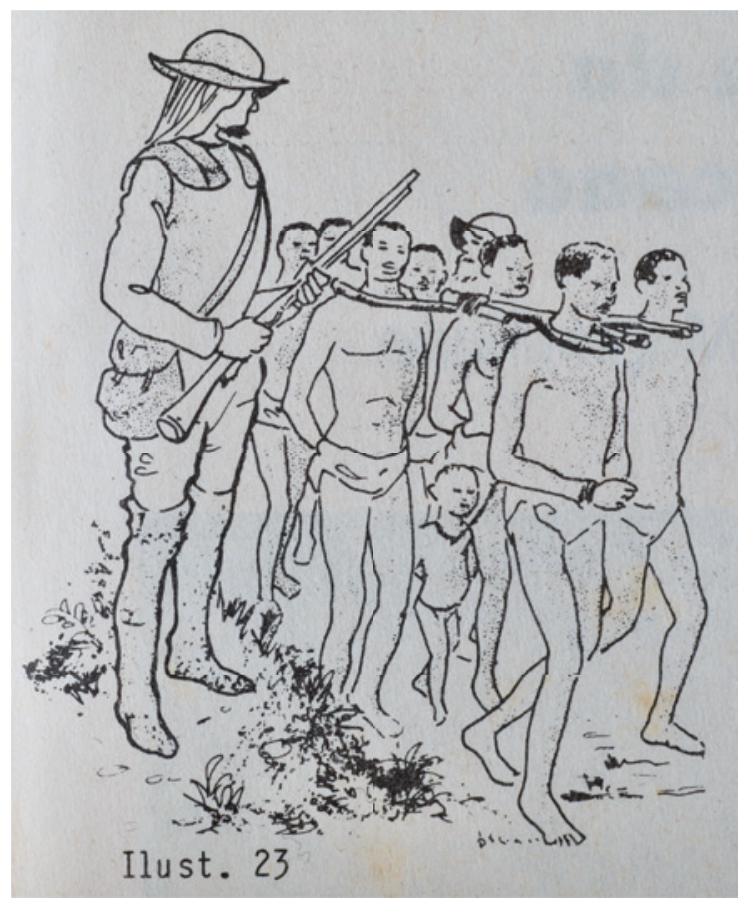

Source: INDE, A História da minha pátria. $5^{a}$ classe, 1986, p. 41. 
In relation to imperialism, Mussa (2015) focuses on the causes and consequences of European expansion, the partition of Africa and the imperialist contradictions of the late nineteenth century until the end of World War I, the so-called "pacification wars" and Mozambican resistance, colonial rule and racism, World War II and the pan-African anti-colonial liberation movements. The textbook emphasises how colonial rule, rooted in the idea of "white superiority", differentiated between Africans and Europeans, in political, economic, religious, administrative, educational, legislative and judicial domains. In all areas of life, this duality of criteria meant that the infra-structures, education and health services developed during the colonial era primarily benefited the colonisers. A concrete example was the existence of a two-tier "legal" system where problems involving Europeans fell under colonial jurisdiction, while litigation solely between Africans was settled using traditional local laws.

Both textbooks directly criticise the education system during the colonial area, for "preaching the doctrine of submission" (Mussa, 2015:49) and attempting to achieve forced assimilation of Mozambican people: "The Portuguese colonialists tried to convince Mozambicans that they were Portuguese. Mozambicans should only speak Portuguese and no longer speak their mother tongues; they should only dance Portuguese dances, sing Portuguese songs and learn the history and geography of Portugal." (INDE, 1986:57). However, the textbook emphasises that Mozambican people always resisted this forced assimilation and "never stopped speaking their mother tongues" (INDE, 1986:57).

In particular, both textbooks denounce the harmful effects of the Statute of Indigenous Peoples:

The Portuguese colonialists created two types of education in Mozambique: one, for the colonists ' children, called official education and the other called basic primary education, which was only for Mozambicans. The first type of education only existed in the cities, while the second type was found primarily in missions, given by missionaries, especially Catholic missionaries. The missionary schools taught the few Mozambicans who could go to school to read and write. They also taught us to be shoemakers, bricklayers, tailors and other professions that generated profits for the colonialists. Mozambicans were never taught to be doctors, teachers, skilled workers or engineers. [...] After completing Basic Primary Education and passing the 4th grade exam, a Mozambican could stop being 'indigenous', because he or she already knew how to speak Portuguese, and already dressed, danced and sang Portuguese music and songs. These Mozambicans could therefore be called 'assimilated' 
(INDE, 1986:57).

Both textbooks contrast colonial education with the education implemented in the liberated areas during the armed struggle:

In colonial schools they taught the history and geography of Portugal and not of Mozambique. Portuguese colonialists wanted to transform Mozambicans into Portuguese people with black skin. In the liberated areas, schools suffered many problems, but the students, teachers, guerrillas, militias and peasants joined forces to solve their problems." (INDE, 1986:84).

While INDE (1986) presents several photos of the liberated areas, including schools, health services and work, Mussa (2015) only shows one photo with the freedom fighters (Image 7).

INDE (1986) notes that during the armed struggle "everyone helped defend the country. Children and women took food and weapons to safe places while men fought" (p. 82), adding that "women also actively participated in the defence of the liberated areas. Many were FRELIMO guerrillas" ( $p$. 84). In reference to "Women in the armed struggle", emphasis is placed on Josina Machel (Image 8) and other freedom fighters, in particular Mónica Chitupila, whose testimony is quoted to highlight FRELIMO's fight against sexism: through the struggle "I learned that equality between men and women was possible" (INDE, 1986:86).

Image 7: FRELIMO's freedom fighters

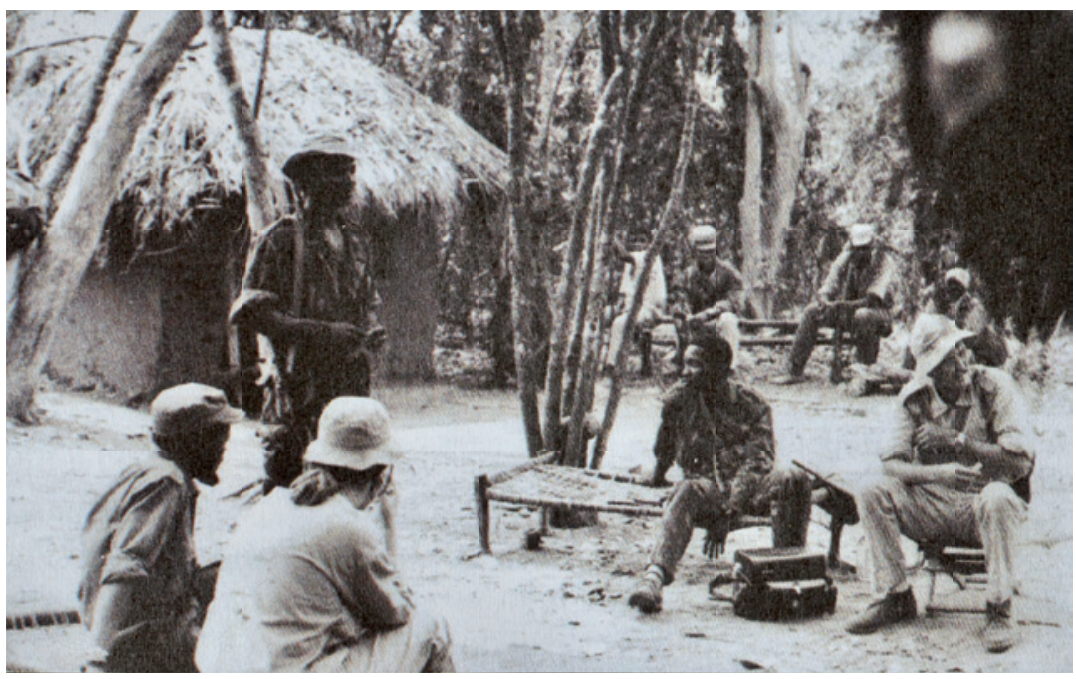

Source: C Mussa, História 12a classe, 2015, p. 139. 
Image 8: Josina Machel

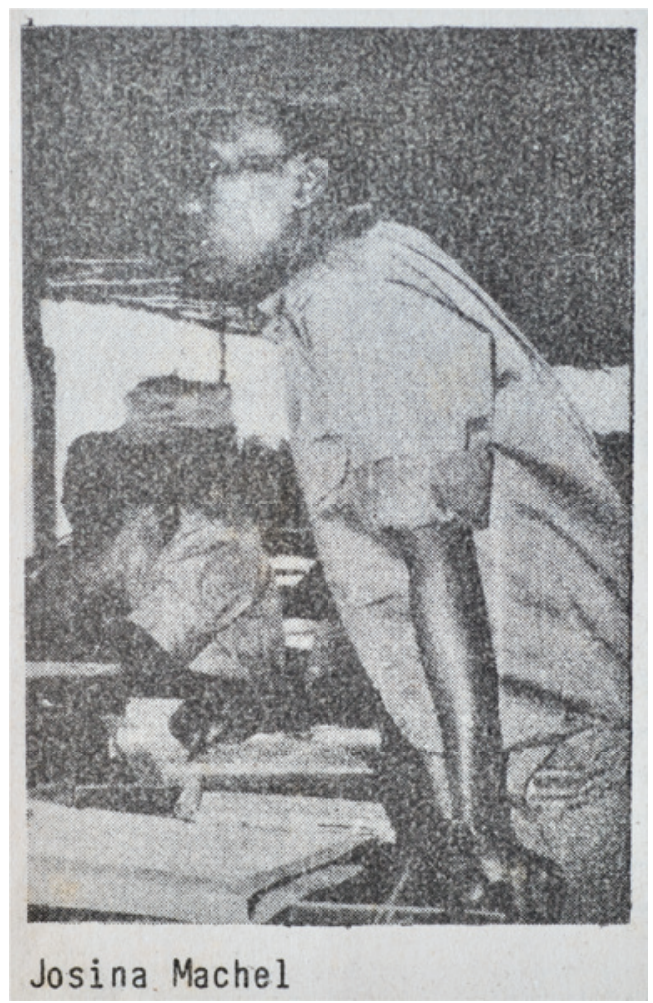

Source: INDE, A História da minha pátria. $5^{a}$ classe, 1986, p. 86.

INDE explains that "in the national struggle, national unity developed. [...] people from different regions of Mozambique felt increasingly united - all were Mozambicans - and were fighting against the same enemy Portuguese colonialism" (1986:86). The former freedom fighter Rita Mulumua is quoted: "FRELIMO showed us that we are one people. We unite to destroy colonialism. [...] The songs, dances, stories and other things were no longer just yao, maconde, or changana, because everyone practiced them, regardless of where they came from. They simply became part of Mozambican culture" (INDE, 1986:87). In contrast, in Mussa (2015) no woman is quoted or appears an image with her name, despite women's active role during the liberation struggle.

The chapter on "Independent Mozambique", INDE highlights Samora Machel's speeches, explaining that now "schools and hospitals started to serve the People" (1986:93) while in the colonial period they primarily served the exploiters. It notes that "the Mozambican people, during the 
armed struggle, were supported by peoples", and now the government of Mozambique "support the peoples who fight against colonialism and racism", namely "the people of Zimbabwe, Namibia and South Africa", in their struggle "for a non-racial and popularly-elected government, which represents the interests of the majority" (INDE, 1986:98). The textbook then describes the process of National Unity, emphasising that this work is obstructed by "South African aggression": "South Africa attacks Mozambique because it is a free and independent nation. Men, women, old people and children of all colours live and work together. They attack us because we fight tribalism, exploitation and racism" (1986:103). It emphasises that "South Africa continues to recruit, train and equip armed bandits" and to intensify "actions of persecution and destruction" within Mozambican territory, but states that the "armed bandits will be defeated" (1986: 106). These indirect references to the civil conflict no longer appear in the current textbook (Mussa, 2015), which in turn, emphasises the end of the civil war, the end of the "Cold War", and the collapse of the racist Apartheid regimes in Southern Africa.

Mussa (2015) emphasises that the liberation struggle in Mozambique occurred against the background of growing African nationalism and pan-Africanist movements, showing photographs of several key African nationalists involved in the fight against colonialism and apartheid. The last chapter, dedicated to national independence, explains that the racist regimes in neighbouring countries took action to weaken the FRELIMO government, which helped peoples in their fight against apartheid (curiously, Nelson Mandela is the only person illustrated with an individual photograph in this chapter on national independence). The importance of international alliances is stressed, in particular with non-aligned countries and regional supranational organisations, such as SADC, PARPA and PARP. The textbook ends with a brief reference to the civil war and the national reconciliation process, stressing the importance of democracy and the fact that FRELIMO once again won the elections.

\section{Discussion: Faces and voices of Mozambican history}

As mentioned above, our analytical framework was based on an intersectional approach. Among other aspects, we analysed what kind of roles were ascribed to different people (whether or not they were "historical figures") and the asymmetries of power that are (explicitly or implicitly) conveyed by both textbooks. We verified whether each person is identified 
with a name; whether they are quoted; whether they are shown on their own (individualised) or in group; and whether they are portrayed in a position of power.

Male faces and quotations are overwhelmingly predominant in both textbooks, portrayed in multiple roles. Although most of the faces and quotations are of FRELIMO leaders in both textbooks, INDE (1986) quotes and shows images of various people, including peasants and female freedom fighters (for example, Image 8). No female voices or faces appear in Mussa (2015), and there are only occasional references to women, such as the writer Noémia de Sousa, the freedom fighter Josina Muthemba Machel, and to Precild Gumane, FRELIMO Women's League secretary. No woman is quoted or represented with an image with her name identified. In fact, a very small image of an anonymous "ancient woman" (Image 2) - placed at the bottom of an even-numbered page, almost goes unnoticed - and is the only photograph representing a woman in the entire textbook. No woman, identified with a name, appears in the illustrations, not even in relation to the liberation struggles. This oversight is therefore not just a question of the lack of images from a "Mozambican perspective". The richness and diversity of the Mozambican archive is therefore not mobilised in the most recent textbook about Mozambican History.

Another puzzling finding is the use of photographs that implicitly reinforce colonial hierarchies. As mentioned above, ironically, in Mussa (2015) the image chosen to identify Unit 1, dedicated to the periodization of Mozambican history, is a photograph of a bas-relief representing the imprisonment of Ngungunyane, which is considered to be the moment that signals the beginning of Portugal's "effective occupation" of Mozambique (Image 3). Ngungunyane, who is the only Mozambican person identified in images in this textbook concerning the periods prior to independence, is portrayed in a position of submission, with downcast eyes, surrounding by the Portuguese in haughty positions. The fact that photographs of these bas-relief are shown three times is puzzling, especially given that there are other photographs of Ngungunyane available, in a dignified position, one of which is used in a very small size at the bottom of an even-numbered page (Mussa, 2015: 78). Why are there no images of other people who symbolised colonial resistance, in particular from other regions of Mozambique? Why are the original drawings presented in INDE (1986), which convey a challenging view of the colonial past (for example, Image 5) not included in the current textbook? It is impossible to answer these 
questions without studying how Mozambican textbooks are currently produced and the role of foreign aid and foreign publishing houses. In fact, if we observe who is given a voice or a face underlines how much still remains to be done to decolonise historical knowledge.

\section{Conclusions}

In this article we have explored how the colonial past and the nationbuilding process are narrated in two Mozambican History textbooks, one published during the single-party period (INDE, 1986), and the other one currently in use (Mussa, 2015). Although there are changes in the type of language used and the type of images chosen to illustrate the colonial past and the liberation process, the general account of Mozambican history is identical in both textbooks, presenting the colonial liberation struggles at the core of the nation-building process. However, the erasure of the agency of women is particularly evident in the current textbook.

Since the beginning of the liberation struggle, the teaching of history was viewed as a priority in order to decolonise people minds and build national unity. Colonialism is described as a violent process, which disrupted African societies and its devastating consequences explain current divisions and underdevelopment. The invasion of the national territory, the exploitation of its natural and human resources, the slave trade, the discriminatory and racist colonial rule are the main subjects addressed in both textbooks, as well as the strong and enduring resistance against colonialism and the liberation struggle. Both textbooks emphasise that the long resistance against foreign occupation failed to be fully effective because Mozambicans were disunited and because of betrayals by several local chiefs who established alliances with the foreign invaders. Both textbooks illustrate how colonial rule differentiated between Africans and Europeans in political, economic, religious, administrative, educational, legislative and judicial domains. In all areas of life, the dual criteria meant that the infra-structures, education and health services developed during the colonial era only benefited the colonisers and not the local people.

While INDE (1986) relies mainly on oral sources and original images (drawings, photos and maps) to build a history from the Mozambican perspective, the current textbook (Mussa, 2015) is richer in resources (coloured images, documents, sources) but essentially depends on the colonial archive for images to illustrate the history of Mozambique prior to independence. In fact, Mussa (2015), in line with the requirements of 
"multicultural education" attempts to offer a more balanced vision of the past in terms of its verbal account, but the different perspectives are simply juxtaposed. There is limited engagement with diversity, achieved through more information about the ways of life of different peoples in the various regions of Mozambique, but this attempt at inclusion is not anchored in images or quotations of people's voices.

Overall, both textbooks convey an official history (Wertsh, 2002) that legitimises the current ruling elite, under the umbrella of a simplified Liberation script that depends on binary opposites - in particular exploiter vs. exploited (Coelho, 2013). Although with some nuances, arising from the political situations in Mozambique and abroad, both textbooks adopt a narrative of agency, stressing the ingroup's successful resistance against foreign oppression and highlighting the heroic role played by several actors during the armed struggle for independence, who are acclaimed as national heroes. There is also a narrative of suffering, which stresses the profound undermining effects of colonial rule.

While all Mozambicans - men and women - are depicted as victims of the colonialism, women are referred to as dual victims, suffering two oppressions - colonialism/imperialism and tradition/tribalism -, especially in INDE (1986). Both textbooks emphasis the fight against colonialism and racism, but whereas, in the context of the single party period, the fight against "tribalism" is one of the main focuses of concern (INDE, 1986), in the context of the multi-party period the fight against tribalism vanishes, giving room to approach issues on cultural diversity (Mussa, 2015). However, that goes in tandem with an absence of references to the fight against sexism and the erasure of women's agency in the current textbook.

In fact, as in other postcolonial contexts, the Liberation script disseminated in the Mozambican textbooks erases women's agency, and this erasure is particularly evident in the current textbook (Mussa, 2015) where no women is quoted or identified with an individual image (photograph or other type of illustration). Despite the fact that women played an active role in the armed liberation struggle, and despite the fact that the fight against sexism, alongside the fight against racism, was one of the pillars of FRELIMO's propaganda, in the absence of either a name or face, women are simply not recognised as agents of history. 
This striking exclusion of women from the narrative script of the nation, especially in the current textbook, echoes Spivak (2014): "Although liberation struggles forced women into apparent equality in the 19th century or even earlier, when dust settles, the postcolonial nation returns to the invisible, long-term gender structures [...]. Colonised and coloniser unite in gender violence", erasing women as an agent of history. In fact, the reproduction of the former sexist colonial order in many postcolonial states challenges the clear-cut binary opposition between the colonial and postcolonial. Questioning binaries is precisely one of key requirements of a truly decolonial approach.

Some of the trends we observed in these two Mozambican history textbooks are also found in other Southern African countries and beyond. As explained by Cajani, Lässig and Repoussi (2019:7), the new independent countries "have felt first and foremost a need to nationalise their history in order to assert and consolidate their independence as a nation" and "they are challenged to construct a narrative showing in a meaningful way the entanglements of the pre-colonial, colonial and post-colonial period", a complex task that "inevitably encompass divided memories". According to the authors, nowadays "History teaching in many African countries persists in taking a Eurocentric or nationalist view", citing the UNESCO Harare Newsletter (January-March, 2012:4), which states that History education in Africa is "disproportionately focused on the colonial period" (Cajani et al, 2019:4). Are these two tendencies - Eurocentric and nationalist - opposed, or they are merely two sides of the same coin? This is a complex question which deserves a multi-layered critical analysis of the particular configurations and reconfigurations in each Nation-State according to its specific historical, cultural and socioeconomic context and political contingencies.

In a commentary paper about the representations of the colonial past in textbooks in several countries, Wassermann (2018:267) pointed out that "Western sources and historical actors were overwhelmingly foreground" in current textbooks. All in all, although there is "a marginal decrease in Eurocentrism in favour of a more balanced interpretation", the changes portray "snippets to cling to rather than an actual decolonial turn" (Wassermann, 2018:267). In fact, building decolonial perspectives remains a very challenging task. It is not just about making visible the colonial oppression and inverting the value systems of the Eurocentric narratives. It requires challenging the paradigms, social categories and 
binary systems forged during the colonial periods and also to engage fully with the diversity of memories and experiences (Cabecinhas \& Brasil, 2019; Quijano, 2000). Moreover, it requires the creation of the material and symbolic conditions that allow the participation of all Mozambicans, men and women, in expressing their own stories and listening to the stories of others. A true decolonial turn is extremely difficult to achieve and requires social justice, dialogue, respect and a profound engagement with diversity, with all its complexity.

\section{Acknowledgement}

Article developed in the scope of "Knowledge for Development Initiative", supported by the Aga Khan Development Network and the FCT - Foundation for Science and Technology, IP (no. 333162622), under of the project "Memories, cultures and identities: how the past weights on the present-day intercultural relations in Mozambique and Portugal?".

\section{References}

Arnfred, S 2004. Conceptions of gender in colonial and post-colonial discourses: The case of Mozambique. Gender activism and studies in Africa, 108-128. Cordesia: Dakar.

Jerónimo, MB 2015. The 'Civilising Mission' of Portuguese colonialism, 1870-1930. Cham: Palgrave.

Barnes, B 1982. On the extensions of concepts and the growth of knowledge. Sociological Review, 30(1):23-45.

Basílio, G 2010. O Estado e a Escola na construção de identidade política Moçambicana [State and school in the Mozambican political identity construction]. Unpublished PhD thesis. Pontifícia Universidade Católica, São Paulo.

Bentrovato, D 2018. 'Decolonizing the mind'? Historiographical perspectives on modern imperialism and colonialism in Zimbabwean post-colonial history textbooks (1980s-current). In: K van Nieuwenhuyse \& JP Valentim (Eds.), The colonial past in history textbooks. Historical and social psychological perspectives, 177-197. Charlotte, NC: Information Age Publishing.

Cabaço, J 2007. Moçambique: Identidades, colonialismo e libertação [Mozambique: Identities, colonialism and liberation]. Unpublished $\mathrm{PhD}$ thesis. Universidade de São Paulo: São Paulo. 
Cabecinhas, R \& Brasil, JA 2019. Social representations of history in the global South: remembering the colonial past from the margins. In: S Seidmann \& $\mathrm{N}$ Pievi (Eds.) Identidades y conflictos sociales. Aportes y desafios de la investigación sobre representaciones sociales, 489-518. Ed. de Belgrano: Buenos Aires.

Cabecinhas, R \& Feijó, J 2010. Collective memories of Portuguese colonial action in Africa: Representations of the colonial past among Mozambicans and Portuguese youths. International Journal of Conflict and Violence, 4(1):2844.

Cabecinhas, R, Macedo, I, Jamal, C, \& Sá, A 2018. Representations of European colonialism, African resistance and liberation struggles in Mozambican history curricula and textbooks. In: K van Nieuwenhuyse, \& JP Valentim (Eds.), The colonial past in history textbooks. Historical and social psychological perspectives, 217-237. Charlotte, NC: Information Age Publishing.

Cabecinhas, R, Jamal, C, Sá, A \& Macedo, I 2021. Colonialism and liberation struggle in Mozambican History textbooks: A diachronic analysis. In: I Brescó \& van Alphen, F (Eds.), Reproducing, rethinking, resisting national narratives. A sociocultural approach to schematic narrative templates. Charlotte, N.C.: Information Age Publishers.

Cajani, L, Lässig, S, \& Repoussi, M (eds.) 2019. The Palgrave Handbook of conflict and history education in the post-cold war era. Cham: Palgrave Macmillan.

Carretero, M, Berger, S, \& Grever, M (Eds.) 2017. Palgrave Handbook of research in historical culture and education. London: Palgrave Macmillan.

Castiano, JP 2019. Os tempos da Educação em Moçambique. In: JP Castiano, R, Raboco, DP, Pereira, S Muianga, \& MJ Morais (eds.) Moçambique Neoliberal. Perspectivas críticas teóricas e da práxis, 275-279. Quelimane: Ethale Publishing \& Editora Educar.

Chakrabarty, D 1992. Postcoloniality and the artifice of history: Who speaks for 'Indian' pasts? Representations, 37:1-26.

Coelho, JPB 2013. Politics and contemporary history in Mozambique: A set of epistemological notes. Kronos, 39(1):20-31.

Crenshaw, K 1991. Mapping the margins: Intersectionality, identity politics, and violence against women of color. Stanford Law Review, 43(6):1241-1299.

Gasperini, L 1989. Moçambique: Educação e desenvolvimento rural [Mozambique: Education and rural development]. Roma: Edizioni Lavoro. 
INDE 1986. A História da minha pátria. $5^{a}$ classe [The history of my homeland. Year 5]. Maputo: INDL.

Isaacman, A, \& Isaacman, B 1983. Mozambique: From colonalism to revolution, 19001982. Boulder: Westview Press.

Israel, P 2013. A loosening grip: The liberation script in Mozambican history. Kronos, 39:10-19.

Kress, G \& Van Leeuwen, T 2001. Multimodal: The modes and media of contemporary communication discourse. London: Arnold.

Lopes, JA 1998. The language situation in Mozambique. Journal of Multilingual and Multicultural Development, 19(5):440-486.

May, VM 2015. Pursuing intersectionality, unsettling dominant imaginaries. New York: Routledge.

Mazula, B 1995. Educação, Cultura e Ideologia em Moçambique: 1975-1985 [Education, Culture and Ideology in Mozambique]. Lisboa: Afrontamento.

Meneses, MP 2011. Images outside the mirror? Mozambique and Portugal in world history. Human Architecture: Journal of the Sociology of Self-Knowledge $\mathrm{X}(1): 121-136$.

MINED 2012. Education strategic plan 2012-2016. Académica: Maputo.

Moscovici, S 1988. Notes towards a description of social representations. European Journal of Social Psychology, 18(3):211-250.

Mussa, C 2015. História $12^{a}$ classe [History, Year 12]. Maputo: Texto Editores.

Piepiorka, A 2020. Exploring "socialist solidarity" in higher education: East German advisors in post-independence Mozambique (1975-1992). In: D Matasci, MB Jerónimo, \& HG Dores (Eds.) Education and development in colonial and postcolonial Africa, Global histories of education. Cham: Palgrave Macmillan.

Quijano, A 2000. Colonialidad del Poder y Clasificacion Social. Journal of world-systems research, 6(2):342-386.

Schefer, R 2016. Mueda, Memória e Massacre (Mueda, Memory and Massacre) by Ruy Guerra and the cultural forms of the Makonde Plateau. Comunicação e Sociedade, 29:53-77. 
Sumich, J 2010. The party and the state: Frelimo and social stratification in post-socialist Mozambique. Development and Change, 41(4):679-698.

Spivak, GC 2014. Preface. In: G Olsson (Director). Concerning violence. Sweden, Finland, Denmark, USA [Film].

UNESCO 2019. Revisão de Políticas Educacionais. Moçambique [Revision of Educational Policy]. Paris: UNESCO.

Valentim, JP \& Miguel, I 2018. Colonialism in Portuguese History textbooks: A diachronic psychosocial study. In: K van Nieuwenhuyse, \& JP Valentim (Eds.), The colonial past in history textbooks. Historical and social psychological perspectives, 133-154. Charlotte, NC: Information Age Publishing.

Van Nieuwenhuyse, K, \& Valentim, JP (Eds.) 2018. The colonial past in history textbooks. Historical and social psychological perspectives, 217-237. Charlotte, NC: Information Age Publishing.

Wassermann, J 2018. Perspectives on representations of colonial pasts through textbook analysis - Not quite a decolonial turn. In: K van Nieuwenhuyse, \& JP Valentim (Eds.), The colonial past in history textbooks. Historical and social psychological perspectives, 261-276. Charlotte, NC: Information Age Publishing.

Wertsch, JV 2002. Voices of collective remembering. Cambridge: Cambridge University Press. 